\title{
Rethinking the concept of intercultural conflict: Italian returnees' attitudes towards others during a cultural conflict.
}

Mattia Baiutti

Università di Roma "Tor Vergata". mattia.baiutti@gmail.com

\author{
Keywords: \\ Intercultural conflict \\ intercultural competence \\ intercultural attitude \\ cultural conflict \\ high school student.
}

Mattia Baiutti, Rethinking the concept of intercultural conflict: Italian returnees' attitudes towards others during a cultural conflict. 


\begin{abstract}
The article aims to rethink the concept of intercultural conflict. Specifically, I argue that the use of the adjective "intercultural" within 'intercultural conflict' is usually an expression of rhetorical discourse or is not appropriate. Following a semantic analysis I show that a cultural conflict, here conceptualized as incompatibility of cultural values between a minimum of two people belonging to different cultural backgrounds, might be described as an intercultural conflict. This is possible if the interactants, rather than focussing on solutions, adopt an 'intercultural attitude' (comity, ethical relativism, critical self-reflection, openness toward a potential change, suspending judgment, reframing meanings, curiosity, respect, and self-decentralization) between them. Existing theoretical concepts are explored through qualitative research examining supposedly interculturally competent high school students' (after one scholastic year abroad) attitudes towards others during a cultural conflict. The study shows that curiosity and respect towards others might be considered as preconditions for a true dialogue. Two main attitudes emerge from the analysis: the multicultural one and the intercultural one. The former corresponds to respect for the different ideas of others. The second is exemplified by true interaction between interactants who seek a deep understanding of what is behind the point of view held by themselves and others. Adopting an intercultural attitude, they make all possible efforts to truly encounter each other's otherness.
\end{abstract}


We have got on to slippery ice where there is no friction and so in a certain sense the conditions are ideal, but also, just because of that, we are unable to walk. We want to walk: so we need friction. Back to the rough ground!

\section{Wittgenstein (Philosophical investigations)}

\section{Introduction}

In this era of globalization, new technologies and other radical changes, such as cheaper and faster transportation, have brought a growth of virtual and real migration. As a result, more than ever before, people who belong to different cultural backgrounds ${ }^{1}$ inevitably have to live and work together. New social orders, as well as new local and global orders seem to be necessary because, as Dan Landis argues, "migrations are likely to produce inter-ethnic conflict which will become severe and on a scale not seen before if not handled with sensitivity and creativity" (2008: 346).

Several scholars (e.g., Gundara, 2000, 2014) and international organizations (e.g., Council of Europe, 2008; Council of the European Union, 2008; Unesco, 2013) have stated that one possible way to manage and, hopefully prevent, such conflicts could be to encourage the development of interculturality among citizens. However, it is important to maintain firmly a "critical vigilance" (Weil, as quoted in Phipps, 2014: 110) on suggestive claims to interculturality and to uncover the various "discourse[s]" (Blommaert, 2005) around this concept. Applying what Wittgenstein calls grammatical investigation (1958: 37), understanding the meaning of the words focusing on their "use" (1958: 18) within "language-game[s]" (1958: 10), we should unmask and understand rhetoric ${ }^{2}$ (Perelman \& Olbrechtd-Tyteca, 1958; Zoletto, 2002, 2008, 2012; Albarea \& Zoletto, 2006) hidden behind claims to interculturality ${ }^{3}$.

As history has shown, living together peacefully is not automatically natural or simple. In order to do this, one often heard suggestion is that people with different values and beliefs, languages, religious, norms, gender, ethnicity, and ways of thinking should acquire competences that are similar to those once only ambassadors and diplomats were expected to develop (Byram, 1997: 1; Spitzberg \& Changnon, 2009: 7). More specifically, it seems to be essential and urgent for all citizens who live in today's diversifying and heterogeneous societies to acquire what scholars and international agencies define as 'intercultural

1 Against an essentialist conceptualisation of culture (Holliday, 2010, 2011), the idea of cultural backgrounds used here is drawn from a wider concept of culture, which also takes account of elements such as gender, age, and social status. It is a dynamic concept, which is linked to the biographies of individuals (or groups) and their interactions in specific, heterogeneous contexts (Zoletto, 2012).

2 The concept of rhetoric is understood here as a "strings of words, images and arguments by which individuals, groups and organizations try to support and make effective their cultural, social and political claims and project" (Zoletto, 2008: 350).

3 Different methods might be involved in order to weaken such rhetorical discourses. For instance, as far as intercultural dialogue goes, Alison Phipps has adopted an ethnographic approach in order to emphasize that intercultural dialogue does not work and make sense everywhere: for example she argues that intercultural dialogue might be "dangerous when used in situations of conflict, vulnerability, insecurity and aggression" (Phipps, 2014: 115). By contrast, the power hierarchies and the paradoxes of the governance of diversity included in the White paper on Intercultural Dialogue (2008) have been revealed with a lexical and semantic analysis conducted by Lähdesmäki and Wagener (2015). 
competence' (e.g., Barrett, 2011; Bennett, 1993; Byram, 1997; Fantini, 2000; Deardorff, 2006, 2008, 2009; Hunter, White \& Godbey, 2006; Spitzberg \& Changnon, 2009; Bortini \& Motamed-Afshari, 2012; Unesco, 2013; Portera, 2014).

Discussing the complex and contested nature (Spitzberg \& Changnon, 2009) of intercultural competence in greater depth is beyond the scope of this article. Rather, the focus is on one specific and thorny aspect of this competence: the ability to manage cultural conflicts, or, as some scholars have labelled them, intercultural conflicts. More specifically, what is the interculturally competent person's attitude towards others during a cultural conflict?

At the same time, the expression "intercultural conflict" might appear meaningless or at least unclear. Indeed, how may a conflict be intercultural? Is intercultural conflict synonymous with cultural conflict? It is interesting that sometimes scholars tend to use the term intercultural conflict without an adequate explanation of what they mean by it, leaving it vague.

The paper seeks to understand some of these issues. Precisely, the driving questions of this paper are the following:

- What might intercultural conflict mean?

- What is the attitude of an interculturally competent person towards others during a cultural conflict?

Therefore, the purpose of this article is twofold:

- To introduce a theoretical discussion about the concept of intercultural conflict; and

- By way of illustration, to provide an empirical example by exploring the attitude of supposedly interculturally competent people (high school students who participated in an annual exchange program) towards others during a cultural conflict.

The article is divided into four parts. Firstly, the article presents and critically discusses a selection of theories and definitions relevant to the above questions. In this section I especially consider the development of intercultural competence of high school students after one year abroad in order to explain why I have investigated students' attitudes towards others during a cultural conflict. This section also draws attention to the general conceptualization of the adjective "intercultural" in an attempt to avoid misunderstanding in my argumentation on intercultural conflict. I refer mainly to Portera's (2008, 2011; Gundara \& Portera, 2008) semantic analysis of intercultural education in Europe. Moreover, Stella Ting-Toomey \& John G. Oetzel's (2013a; see also 2001, 2013b; Ting-Toomey, 2007a, 2007b, 2009; Oetzel, Dhar, \& Kirschbaum, 2007) definition of intercultural conflict, one of the most influential ones, is briefly presented and problematized. Consequently, diverse theoretical reflection on the concept of intercultural conflict is addressed.

The second part of the article presents a description of the empirical research and its limitations.

In the third part, findings of the empirical research are presented and critically discussed. This part demonstrates that two different attitudes towards others during a cultural conflict emerged from the data gained from high school students who spent one year abroad, here called returnees. I define these attitudes as multicultural and intercultural. The final part presents general conclusions emerging from insights on the theoretical concepts gained through the empirical research. 


\section{Relevant theoretical concepts and definitions}

\subsection{Student mobility and intercultural competence}

A changing world is a world that questions education. Consequently, school institutions cannot ignore the fact that today's citizens need new competences, such as intercultural ones. Accordingly, educational institutions should create and encourage suitable programs, activities, and experiences to allow students to develop the knowledge, skills and attitudes that are necessary to live and work within heterogeneous and interconnected societies.

Intercultural and international education, which has gradually become more crucial and urgent, is currently understood as "the most appropriate response to the challenges of globalisation and complexity" (Portera, 2008: 488. See also, 2011).

Student mobility represents a valuable means of promoting intercultural and international education. From a pedagogical point of view, this particular kind of migration takes place in formal, non-formal and informal contexts. One meaningful outcome of this kind of student experience is the development of intercultural competence (Deardorff, 2006: 241). Studying abroad, however, is not enough to become an interculturally competent individual (Deardorff, 2009). Before, during and after an intercultural experience, adequate preparation is required (Savicki, 2008; Deardorff, 2008, 2009) because, as Deardorff notes, "intercultural competence doesn't just happen" (2009: xiii).

Research concerning the topic of intercultural competence and student mobility is usually focused on students in higher education. Few theoretical and empirical studies have paid attention to high school students (eg., Ruffino, 1981a, 1981b; Hansel, 1986; Unesco, 1987; Hammer, 2005).

However, one study is important to mention: that conducted by Mitchell R. Hammer (2005) in partnership with AFS Intercultural Programs. Hammer's research aimed to assess the impact of the AFS study abroad experience. A total of 2100 high school students from nine countries participated in the study and they were evaluated before, during and after a program abroad. Out of the total number, 1500 were AFS participants who lived and studied in another country for ten months and 600 were peers who did not have an experience of study abroad. The study was based on a comprehensive model for measuring one's intercultural sensitivity, the Developmental Model of Intercultural Sensitivity (DMIS), created by Milton Bennett (1993). The principal measurement tool used was the IDI (Intercultural Development Inventory) designed by Hammer, Bennett and Wiseman (2003). The tool allows an interpretation of an individual's predominant worldview in terms of how he or she experiences other cultures. The empirical research demonstrated that the benefits received from a long-term international school program, beyond the foreign language fluency levels achieved, personal growth, and a wider knowledge of the host culture, include a development of intercultural competence defined as "the capacity to generate perceptions and adapt behaviour to cultural context" (2005: 2).

This extensive study has demonstrated that high school students, living completely within a different cultural environment and coping with rather new and unfamiliar difficulties, have often developed intercultural competence. Therefore, assuming that returnees are interculturally competent, they are eligible to be investigated in order to explore their attitudes when they experience cultural conflicts, as the empirical research, presented here, has done.

Mattia Baiutti, Rethinking the concept of intercultural conflict: Italian returnees' attitudes towards others during a cultural conflict. 


\section{2 "intercultural" and 'intercultural attitude'}

Before beginning the discussion about intercultural conflict, it is helpful to clarify how this article uses the adjective "intercultural". "Intercultural" is an umbrella adjective used in many different and not necessarily compatible ways: "there is an on-going failure to provide a clear semantic definition or distinct epistemological foundation for the concept" (Portera, 2008: 484). To rectify this lack of clarity, this article draws upon Portera's chronological and semantic analysis (2008; 2011; Gundara \& Portera, 2008) of intercultural education in Europe.

Portera (2008, 2011; Gundara \& Portera, 2008) argues that, even though the concept of intercultural education has been adopted since the 1990s in European documents and English-language books, it usually overlaps with other concepts such as transcultural and multicultural education. Although the differences between trans-/multi-/inter-cultural education are not necessarily fixed, Portera attempts to reduce, if not eliminate, the semantic ambiguity among these concepts.

To begin with, transcultural education "refers to elements spreading through culture (as in cross-cultural psychology or transcultural psychiatry)" (Portera, 2011: 18). Relying on the theory of cultural universalism, this kind of education aims "to develop common universal elements: respect, peace, justice, environmental protection, human dignity, autonomy, etc." (Portera, 2008: 484). However, Portera points out some risks hidden behind this worthy approach: firstly, it seems to underpin an unrealistic unitary vision of the world which, in reality, is heterogeneous and fragmentary (Portera, 2008, 2011). Moreover, this approach could become a "new and further form of cultural imperialism" (Portera, 2008: 484) imposing European, or Western, values. Finally, the risk is that everything will be labelled and generalized "uncritically as 'human' without appropriately respecting actual cultural differences" (Portera, 2008: 485).

On the other hand, the purpose of multicultural (or pluricultural) education is to "respect diversities", which means that "the main educational aims are acknowledgment and respect of cultural differences" (Portera, 2008: 485). This kind of approach is based on the principle of cultural relativism (Portera, 2011). Again, several possible risks arise. Firstly, ideas such as culture, social stratification and hierarchical groups may be conceptualised in a static and rigid way (Portera, 2008, 2011). Sometimes, this approach in education might also reduce diversity to concepts "limited to folksy or exotic style" (Portera, 2011: 19) in which people have to identify their cultures (as a pre-configured box) of origin.

Different again is the concept of intercultural education, which Portera defines as a true "Copernican revolution" (2008: 485; 2011). Within that approach, concepts involved in interculturality, such as identity and culture, have to be thought of as something dynamic and evolving, rather than rigid and fixed. Otherness is assumed to offer richness and opportunity. Portera asserts that the intercultural approach, transcending universalism and relativism, "builds up a new synthesis with improved chances of dialogue, exchange and interaction" (Portera, 2011: 20). This idea seems to be fascinating, but, at the same time it is quite unclear, and potentially, rhetorical. Indeed, Portera does not explain precisely what he means by synthesis, how this synthesis is created, or how it resolves or deals with inevitable sensitive and thorny issues, such as cultural dilemmas.

Nonetheless, for the purpose of this article, it is important to emphasize that "the prefix 'inter' [in interculturality] describes the relationship, the interaction, the exchange between two or more persons" (Portera, 2008: 486). In line with this concept of interculturality, I assume that the use of the adjective "intercultural" has a significant correlation with the idea of interaction, an action between (Baiutti, 2015) two or more poles (individuals or 
groups). As Portera states "there is a game, an 'interaction', between people with different ethnic, linguistic and cultural backgrounds in which the aim is not assimilation or fusion, but encounter, communication, dialogue, contact, in which roles and limits are clear, but the end is open" (2008: 488). Consequently, the adjective "intercultural" implies a project, a process of mutual exchange where each person acknowledges the other and is acknowledged by the other. However, this encounter is not always automatic and devoid of threat.

The implicit assumption here is that one of the principal means of dealing more effectively with this kind of encounter is to adopt an attitude, which I call an "intercultural attitude", towards the other. An intercultural attitude is here conceptualized as a sincere attitude of comity (Landis, 2008), ethical relativism, critical self-reflection (Barnett, 1997; FisherYoshida, 2005), openness towards a potential change, suspending judgment, reframing meanings, curiosity (Byram, 1997; Deardorff, 2006), and self-decentralization.

In summary, the adjective "intercultural" is used to mean an interaction between people who have different cultural backgrounds. This interaction is a space where real encounters take place, contacts among differences. However, this interaction might be complicated. Therefore, an intercultural attitude is required in order to facilitate a more effective management of this kind of interaction.

\subsection{Intercultural conflict}

As mentioned above, communicating with people who belong to different cultural backgrounds may not be straightforward and may involve complications. Our daily life provides evidence of this. Various factors, such as different communication styles, languages, norms, beliefs and values, behaviours, or historical implications, might transform an encounter into a conflict ${ }^{4}$, generally called a cultural conflict. The same notion of "conflict", and how to deal with it, might become a reason for disagreement because it varies across contexts, and individuals.

A general discussion about conflicts, however, is not the aim of this article. The focus is on the intercultural conflict at the micro level (interpersonal). One of the most influential definitions and models of intercultural conflict is that drawn up by Ting-Toomey \& Oetzel (2013a; see also 2001, 2013b; Ting-Toomey, 2007a, 2007b, 2009; Oetzel, Dhar, \& Kirschbaum, 2007). They define

intercultural conflict . . . as the implicit or explicit emotional struggle between persons of different cultural communities over perceived or actual incompatibility of cultural ideologies and values, situational norms, goals, face orientations, scarce resources, style/processes, and/or outcomes in a face-to face (or mediated) context within a sociohistorical embedded system (2013a: 635).

How is the word "intercultural" used here? Within this definition, it is not clear which role the adjective "intercultural" plays. As described above, I argue that in order to use this adjective it is necessary that a true encounter between the two parties occurs. Instead, the quoted definition simply seems to focus on describing the situation ("implicit or explicit struggle between persons of different cultural communities") and the reasons why a conflict takes place ("perceived or actual incompatibility of cultural ideologies and values, situational norms, goals, face orientations, scarce resources, style/processes, and/or outcomes in a

4 For a detailed literature review concerning approaches and definitions of conflict communication see Putnam, 2013. 
face-to face (or mediated) context within a sociohistorical embedded system"). Here, likely, "intercultural" is linked to the idea of "different cultural communities". In other words, it seems that because the conflict arises from different cultural backgrounds, then it is appropriate to call it "intercultural". But, as already discussed above, this labelling is an epistemological mistake or, at least, (fashionable) rhetorical discourse.

Moreover, this definition seems to contrast with the dynamic idea of culture, as understood in an intercultural approach. This suspicion is confirmed when Ting-Toomey \& Oetzel define culture as "a learned system of traditions, symbolic patterns, and accumulative meanings that fosters a particular sense of shared identity-hood, community-hood, and interaction rituals among the aggregate of its group members" (2013b: 763). This kind of simplified notion of culture seems grounded on several uncritical assumptions. The first assumption is that cultures "would unequivocally shape the values and social acts of people"5 (Zoletto, 2012: 20; author's translation). Zoletto, quoting Geertz, Wittgenstein, Bateson, and Goffman, argues that "cultures cannot be seen as a top-down batch of rules, imposed upon individuals who should just follow them passively" ${ }^{6}$ (Zoletto, 2012: 21; author's translation). Rather, according to Zoletto, subjects, starting from their face-to-face interactions, establish a given social order, a given culture. This idea seems to echo the concept of "discursive culture" which means to "see culture as discursively constituted" (Shi-xu, 2001: 283). The second assumption is that cultures "would be an already given substance or essence, or at least preconceived and identified"7 (Zoletto, 2012: 21; author's translation). Zoletto, taking inspiration from sociologists and anthropologists such as Geertz and Augè, argues that "not only must culture be conceived as something which continually changes, but above all, it is impossible to disregard the specific perspective of individuals" (Zoletto, 2012: 21-22; author's translation). The final assumption is that our societies "would cease only today to be pure and identical to themselves - and would become multicultural - only because they are increasingly frequented by migrants, exponents of other cultures" ${ }^{\prime \prime}$ (Zoletto, 2012: 22; author's translation). Again, the idea arising in this assumption is that culture "would be something fixed which would realize itself through individuals"10 (Zoletto, 2012: 22; author's translation). But, as Shi-xu argues, "Human culture has the deep - rational - capacity to reand trans-form itself" (2001: 283).

For these reasons (absence of the idea of interaction within the definition, and the concept of culture authors use), the use of "intercultural" within Ting-Toomey \& Oetzel's definition of intercultural conflict is not appropriate or, at least, is unclear. What I would like to propose here is that the expression "intercultural conflict" makes sense if it is defined by reference to a specific type of attitude within a given context. Cultural conflict is here assumed as the incompatibility of cultural values between a minimum of two people belonging to different cultural backgrounds. I argue that what might transform a cultural conflict into an intercultural conflict, or rather permit a cultural conflict to be described as an intercultural conflict, is the attitude towards the others during the cultural conflict. The prefix "inter" in the word "intercultural conflict" stresses the reciprocal intention to truly encounter the other's otherness. Accordingly, rather than being just a conflict, intercultural conflict is a dialogue space where involved participants put themselves on the line with a deep and

5 "modellerebbero in modo inequivocabile i valori di riferimento e l'agire sociale delle persone".

6 "le culture non possono essere viste come batterie di regole rigide calate dall'alto su individui che possono solo seguirle passivamente".

7 "sarebbero sostanze o essenze già date precedentemente, o comunque predeterminate e identificate". 8 "non solo la cultura va concepita come un qualcosa in continua trasformazione, ma soprattutto diventa impossibile prescindere dalla specifica prospettiva degli individui".

9 "cesserebbero solo oggi di essere pure e identiche a se stesse - e diventerebbero invece multiculturali - soltanto perché frequentate sempre più spesso da migranti esponenti di culture altre".

10 "sarebbero qualcosa di definito che si concretizzerebbe in individui". 
authentic engagement in order to experience a real encounter. However, it does not consequently mean that they necessarily achieve an agreement or a solution. Moreover, the idea that the conflict disappears or that it no longer exists is just a kind of rhetorical discourse. What is at stake here is not, or not directly, the result itself, but rather, the way the cultural conflict is approached. Adopting what I have called above an "intercultural attitude" creates a more positive space where participants make all possible efforts to encounter the other (and, in such way, themselves) in their otherness.

In the next section of this article, these theoretical concepts and definitions are explored through a small empirical study.

\section{Brief description of empirical research}

The data on which this empirical research is based were gathered by semi-structured interviews conducted with eleven participants and analysed with a bottom-up approach. The software employed for analysing the data was Nvivo10 (Mac).

The research participants were Italian study abroad returnees who attended high school and participated in annual study abroad programs during the school year 2012/2013, when they were $16 / 17$ years old. At the time of the interviews all participants were 18 years old except one (in that case informed consent to the research was obtained from the parents). They were selected from three different regions of Italy: Friuli Venezia Giulia (3), Lazio (3) and Sicily (5). The programs analysed are those promoted by the Intercultura association, which has been a leading Italian organization in arranging exchange school experiences since 1955. The association is the Italian partner of AFS Intercultural Programs and a member of the EFIL (European Federation for Intercultural Learning). The participants lived with host families abroad and attended local secondary schools as full-time students. In addition, the program offered learning camps and other experiences that guided and supported the students during their entire experience abroad.

For the purpose of this article I consider only the part of the interview where the returnees were asked to explain how they would deal with cultural conflicts, such as: "How would you behave if someone told you: 'From my point of view, female genital mutilation is correct'?"; "How would you react, if someone stated that homosexuals are not human beings?"; and "How do you deal with someone who thinks that the death penalty is necessary?".

The study has several limitations. The most important concerns the proposed task, which was simply to predict how students would react when someone states something they would perceive as strongly "wrong". In other words the task was just a sort of simulation. More realistic data would have been obtained by trying to observe directly the returnees' attitude during a real cultural conflict, but this was not feasible within the constraints of this study.

Another limitation is that, since teenagers' understandings are likely in constant development and change, it would be worthwhile to compare the findings presented here with follow-up interviews, conducted for example several months or years later, in order to understand possible further development of the participants' attitudes towards others during a cultural conflict.

\section{Results and discussion}

Based on the data gathered and analysed, this study suggests the following key findings: firstly, curiosity and respect towards others might be considered as preconditions for a true dialogue; and secondly, two main attitudes - a multicultural attitude and an intercultural attitude - emerge from the analysis. 


\section{Finding 1. Attitude towards cultural differences: curiosity and some limits}

All interviewees showed an attitude of curiosity towards cultural differences. For instance, Sofia" said "sono stata sempre attratta dalle cose totalmente diverse da me"12 and when she had to justify the reason why she had attended a study abroad program she answered: "volevo vedere come una stessa cosa può essere vista da un'altra cultura"13. Another example is Sara, who said "ciò che è diverso tendenzialmente fa paura. A me ciò che è diverso tendenzialmente attrae, perché sono curiosa"14. Curiosity towards otherness might be considered a necessary precondition for encountering others because sometimes "something absolutely present may be invisible" (Cavell, 1979: 396).

At the same time, several participants observed that curiosity about diversity does not always have to transform all differences into something acceptable. For instance, Matteo stated that, although he is attracted to difference, it is important to adopt an "occhio critico" $^{15}$. General ideas such as "non . . . ci sono cose giuste o sbagliate, ci sono cose differenti"16 (Silvia), even if they are worthy ideas, sometimes might appear to be merely rhetorical or uncritical discourse:

"è molto facile dire 'A me piacciono tutti, a me vanno bene tutti, non c'ho problema con la gente'. Poi se arrivi là e scopri che no, non è così, magari hai dei problemi con alcuni comportamenti, alcuni tipi di persone non ti piacciono, non ti ci trovi bene, lo sai solo quando fai il passo e vai là e vedi, te lo provi sulla pelle, perché prima è molto più facile dire effettivamente 'Sì, sono aperto! Sì, mi va bene tutto', poi uno arriva là e fa faccia, fa a cazzotti con la realtà che magari non è così"17 (Roberto).

Therefore, the data show that students thought that statements that tend to be too "politically correct" should be avoided, or at least contextualized, because not all differences are acceptable. The same Sara, indeed, said that "ci sono delle cose basilari su cui non si transige, giustamente ${ }^{\prime 18}$.

Defining a border, however, between differences that are acceptable and those that are not is a complex and controversial issue. Having grown up in a country that purports to have a democratic system of government (Italy), interviewees may be influenced by the culture of human rights and the idea of universalism that arises in them. For example, Matteo said

11 To protect their anonymity, all participants' names have been changed.

12 "I have always been attracted to things that are totally different from me". I have decided to quote, within the article, the interviews in their original language (Italian); footnotes contain an interpretive translation, as it is impossible to express the richness of the discursive interaction.

13 "I wanted to see how the same thing could be seen from another culture".

14 "What is different generally scares most people. For me, what is different, generally, attracts because I'm curious".

15 "Critical point of view".

16 "Things aren't right or wrong, but different".

17 "It is very easy to say 'I like everybody, I get along with everybody, I don't have any problem with anyone'. Then, when you arrive there and you realize that it is not so, maybe you do dislike some behaviors or some kinds of people, you don't like, you really don't feel comfortable with some people, you can only figure this out if you take the plunge and actually you go there and you see, you find out for yourself, because it's easy to say beforehand 'Yes, I'm open-minded! Yes, everything is okay!', then you arrive there and face up to, you crash against a reality, which is not as you thought it was".

18 "There are some things on which a compromise isn't possible, rightly". 
"c'è qualcosa di oggettivamente intollerabile, questo confine lo sanno tutti dagli indiani, ai giapponesi, ai russi";

"secondo me, diciamo, un minimo di standard su questo confine è insito nell'uomo"; and

"secondo me è fattibile, è fattibile trovare un contatto con tutti, con tutti perché secondo me ogni persona riconosce umanamente, essendo essere umano, essendo imperfetto, sensibile, ciò che è rispettoso verso gli altri, ciò che non lo è"19 .

The subjects appeared to accept this viewpoint, which exemplifies a kind of universalism echoing Immanuel Kant, uncritically, as something obvious. Indeed, Matteo seems to believe that all human beings, as such, are able to understand where the border is between what is tolerable and what is not, and this border is objective. As we shall see later, those who adopt an intercultural attitude are more open to challenging the idea of objectivity of this assumption.

\section{Finding 2. Precondition for a true dialogue: respect towards others}

Another issue is whether there is any necessary precondition for developing a real dialogue between people who are involved in a cultural conflict. Participants observed that reciprocal respect among people is fundamentally necessary; otherwise the attempt to encounter each other is useless. Matteo said that he respects the other but, simultaneously, "esigo egual rispetto" 20 . Reciprocal respect seems to be considered a necessary ground for developing a true dialogue.

These two initial findings show that curiosity towards others and reciprocal respect are preconditions for the development of a dialogue where (potentially) people might truly encounter each other even if they have incompatible points of view.

\section{Finding 3. Attitude towards cultural conflict: multicultural}

Bearing in mind Portera's analysis, I would call an attitude which tends to "just" respect differences a "multicultural attitude" towards others during a cultural conflict. A clear example of this attitude is visible in this quote:

"brutto a dirsi, viene prima il rispetto. Non possiamo noi italiani andare in Giappone e uccidere tutti quelli a favore della pena di morte, sarebbe ancora peggio. È una cosa, adesso va beh, è una cosa brutta da dirsi, però è così. Nel senso che io personalmente rispetto, non condivido, ma rispetto" ${ }^{21}$ (Matteo).

19 "there is something objectively intolerable, everyone knows this border exists from Indians, to Japanese, to Russians"; "from my point of view, let's say, a minimum standard concerning this border is inside every human being"; "from my point of view, it is possible to find a contact with everybody because every person humanly recognizes, being a human being, being imperfect, sensitive, what is respectful towards others and what is not".

20 "I demand the same respect".

21 "It's not nice to say, but respect first of all. As Italians, we can't go to Japan and kill everyone who stands in favour of the death penalty, it could be even worse. It's not nice to say, but it's so. I mean, I personally respect it, I don't agree with it, but I respect it". 
From the perspective of a multicultural attitude, respect seems to be understood as the only possible attitude during a cultural conflict. In this case there is not a real effort to enter into dialogue. However, it is important to emphasize that the idea of respect discussed in this sentence is different from the idea of respect claimed as a prerequisite to dialogue. The latter is respect for the person; the former is respect for the person's point of view.

The data have shown that within the multicultural attitude there is a lack of interest toward the motivations that are behind the standpoint of the interlocutors. "Abbiamo usi e costume diversi e la cosa più importante è il rispetto"22 (Silvia). Differences in values are perceived as a fact, rather than a result of a continuous discourse and interaction. Assuming mere respect for another's point of view hides, or at least simplifies, the complex process that takes place during a cultural conflict. In addition, as Portera points out, among other potential consequences, it seems that one consequence of a multicultural approach may be the adoption of an unconditional relativism.

The data show that a multicultural attitude allows, on one hand, coexistence, based on respect, between people who have incompatible points of view; on the other hand, it does not allow a real encounter between them.

\section{Finding 4. Attitude towards cultural conflict: intercultural}

During a cultural conflict, several students would adopt what I have defined above as an "intercultural attitude".

"Io reagire, in primis, cercando di farmi spigare perché 'Tu la pensi così'. Cioè, la prima cosa che faccio non è dirti 'No, guarda, tu hai torto perché io la penso così!'; è 'Tu mi stai dicendo questa cosa, motivala, cerca di farmi capire il perché del tuo pensiero'. Dopo che tu mi dici le motivazioni, io, dopo aver ascoltato, cerco di capire, 'Guarda, secondo me, su questo punto hai ragione, però su quest'altro punto dovresti attenzionare anche l'altra prospettiva'"'23 (Giacomo).

"Io dico la mia opinione, dico 'Guarda secondo me, perché così così' cioè dando una motivazione, e chiedendola la motivazione perché non ha senso dire 'Io penso questo, punto', ma 'Perché? Cioè, spiega, argomenta' e io poi, rispetto a questo posso dirti 'Ok sono d'accordo', posso anche cambiare idea se tu mi dici, cioè le motivazioni buone. Quindi magari sento le tue motivazioni, e poi, in base a questo posso dire 'Ah, sai, forse questo aspetto è giusto però guarda secondo me, c'è anche questo aspetto che magari tu non hai visto'. Che comunque, cioè la realtà è una però può essere vista sotto diversi punti di vista"24 (Elisa).

22 "We have different customs and traditions and the most important thing is respect".

23 "I would react, initially, by asking you to explain me why 'You think so'. I mean, I would never tell you, as a first thing, 'No, listen, you're wrong about it because I think of it differently!'; 'You're telling me this thing, so justify it, try to make me understand the reasons behind your thoughts'. After you have explained your point to me, after I have listened to it, I will try to understand it, 'Look, from my point of view, you are right on this point, but on the other hand you should also take these other aspects into consideration"".

24 "I tell my opinion, I say 'Look, in my opinion, it's that', I mean I give my reasons and I ask for his/her reasons because it doesn't make sense to say 'I think that, stop' but 'Why? Explain, argue your points'. After that I can tell you 'Ok, I agree', I can change my idea if you have given me good reasons. So I hear your reasons and after that I can say 'Maybe this aspect is fine, but, look, in my opinion you should consider also this other aspect'. There is only one reality but it might be seen from different perspectives". 
In this perspective dialogue becomes a real communicative space where, rather than just revealing different ideas, participants want truly to understand the other's (as well as one's own) "life-form[s]" (Wittgenstein, 1958: 10). In so doing, participants are more likely to experience a real encounter and acknowledgement of the other's otherness.

Analysing these students' words, we can see that they are involved in a true interaction and they seek a deep understanding of what is behind their own and others' assumptions. Adopting critical reflection, they try to investigate their assumptions and, in that way, hopefully explain the reasons for their thoughts. This uncovering process permits the students to know themselves better because, in order to be clear with the other, they "need to consider the context and other influencing factors that create the meaning perspectives" (Fisher-Yoshida, 2005: 8) they have. In other words, they need to challenge what is perceived to be obvious for them. At the same time, students ask their interlocutors to do the same.

Participants, as Elisa said, are open to changing their ideas, to reframing their meanings, if the other has a convincing justification. In order to understand the other position, which could be completely opposite, a self-decentralization and an ethnorelative view might be called for.

Finally, I argue that what I have called above an "intercultural attitude" and that which emerged from some of the analysed data, is the attitude that enables a cultural conflict to be described as an intercultural conflict. Indeed, it is the attitude that might create a basis for a true encounter between otherness, because as American philosopher Stanley Cavell wrote

The truth . . . is that we are separate, but not necessarily separated (by something); that we are, each of us, bodies, i.e., embodied; each is this one and not that, each here and not there, each now and not then. If something separates us, comes between us, that can only be a particular aspect or stance of the mind itself, a particular way in which we relate, or are related (by birth, by law, by force, in love) to one another - our positions, our attitudes, with reference to one another. Call this our history. It is our present. (Cavell, 1979: 369.)

Attitudes might separate people but, at the same time, they might be elements of connection, even in a cultural conflict. As several data items show, critical reflection, openness to potentially change ideas and to reframe meanings, self-decentralization and ethical relativism are the keystones that enable a person to come into contact with other's otherness. In this way, a "simple" cultural conflict might be described also as an intercultural conflict. 


\section{Conclusion}

This article has sought to rethink the complex concept of intercultural conflict. In particular, the two driving questions were related (i) to understanding what the expression "intercultural conflict" might mean and (ii) to exploring the attitude of an interculturally competent person towards others during a cultural conflict.

As regards the first question, emphasizing the prefix "inter", I have tried to stress the idea that a cultural conflict, here conceptualized as incompatibility of cultural values between a minimum of two people belonging to different cultural backgrounds, might be described also as an intercultural conflict if the participants, rather then focusing on solutions, adopt an intercultural attitude toward the other. I defined an intercultural attitude as a sincere attitude of comity, ethnorelative view, critical self-reflection, openness towards a potential change, suspension of judgment, reframing of meanings, curiosity, and selfdecentralization. Finally, an intercultural conflict might be considered a dialogue space where participants better understand themselves and others.

As regards the second question, I conducted empirical qualitative research. I interviewed supposedly interculturally competent students, who attended an annual study abroad program, in order to explore their attitudes towards others during a cultural conflict. The study showed that curiosity and respect towards others might be contemplated as preconditions for a real dialogue. Two main attitudes emerged from the analysis. The first was an attitude that I called "multicultural", which essentially "just" respects the other's ideas but does not engage students in a real interaction. The second attitude was the "intercultural" one, within which participants focus on the motivation behind the specific disagreements from which the conflicts arise. In order to encounter the other, it is necessary to take some distance from the individual point of view and try to understand why the other might have a different one. At the same time it is necessary to analyse one's own assumptions. Through these understandings, a true encounter with otherness can arise.

\section{Acknowledgments}

My sincere gratitude goes to Fondazione Intercultura, which funded my doctoral research on which this article is based. Moreover, I would like to thank everyone involved in this research. 


\section{References}

Albarea, R., \& Zoletto, D. (2006). Living the betweenness - Paradoxes and rhetorics: Comparative attitude and educational style. In J. Sprogøe \& T. Winther-Jensen (Eds.), Identity, education and citizenship - Multiple interrelations (pp. 165-174). Frankfurt am Main, D: Peter Lang.

Baiutti, M. (2015). La competenza interculturale per pensare insieme un futuro possibile. MeTis, V (1), 332-339. doi: 10.12897/01.00081

Barrett, M.D. (2011). Intercultural competence. EWC Statement Series, 2, 23-27.

Barnett, R. (1997). Higher education: A critical business. Buckingham, UK: Open University Press.

Bennett, M. J. (1993). Towards ethnorelativism: A developmental model of intercultural sensitivity. In R. M. Paige (Ed.), Education for the intercultural experience ( $2^{\text {nd }}$ ed., pp. 21-71). Yarmouth, ME: Intercultural Press.

Blommaert, J. (2005). Discourse. A critical introduction. Cambridge, UK: Cambridge University Press. http://dx.doi.org/10.1017/CBO9780511610295

Bortini, P., \& Motamed-Afshari, B. (2012). Intercultural competence research report. SaltoYouth Cultural Diversity Resource Centre. https://www.salto-youth.net/downloads/4-17-2740/Intercultural.....

Byram, M. (1997). Teaching and assessing intercultural communicative competence. Clevedon, UK: Multilingual Matters.

Cavell, S. (1979). The claim of reason. Wittgenstein, skepticism, morality, and the tragedy. Oxford, UK: Oxford University Press.

Council of Europe (2008). White paper in intercultural dialogue. Living together as equals in Dignity. Strasbourg, FR: Council of Europe. http://www.coe.int/t/dg4/intercultural/source....

Council of European Union (2008). Council conclusion of 22 May 2008 on Intercultural competences, 2008/C 141/09. http://eur-lex.europa.eu/LexUriServ/LexUriServ....

Deardorff, D. K. (2006). Identification and assessment of intercultural competence as a student outcome of internationalization. Journal of Studies in International Education, 10(3), 241-266. http://dx.doi.org/10.1177/1028315306287002

Deardorff, D. K. (2008). Intercultural competence. A definition, model, and implications for education abroad. In V. Savicki (Ed.), Developing intercultural competence and transformation: Theory, research, and application in international education (pp. 3252). Sterling, VA: Stylus.

Deardorff, D. K. (2009). Implementing intercultural competence assessment. In D. K. Deardorff (Ed.), The SAGE Handbook of Intercultural Competence (pp. 477-491). Thousand Oaks, CA: Sage.

Fantini, A. E. (2000). A Central concern: Developing intercultural competence. http://www.adam-europe.eu/prj/2935/prd/8/1/develop-I-com.pdf

Fisher-Yoshida, B. (2005). Reframing conflict: Intercultural conflict as potential transformation. Journal of Intercultural Communication, 8, 1-16. http://www.humiliationstudies.org/documents/FisherYoshidaReframingConflict..f

Gundara, J. H. (2000). Interculturalism, education and inclusion. London, UK: Paul Chapman. http://dx.doi.org/10.1080/713665241

Mattia Baiutti, Rethinking the concept of intercultural conflict: Italian returnees' attitudes towards others during a cultural conflict. 
Gundara, J. H. (2014). Global and civilizational knowledge: Interculturality, citizenship, and student exchange programmes. Intercultura, 72(1), 3-13.

http://fondazioneintercultura.it/jb/webfiles/Trimestrale...

Gundara, J. S., \& Portera, A. (2008). Theoretical reflections on intercultural education. Intercultural education, 19(6), 463-468.

http://dx.doi.org/10.1080/14675980802568244

Hammer, M. R. (2005). Assessment of the impact of the AFS study abroad experience. New York, NY: AFS Intercultural Programs. https://idiinventory.com/wp-content/uploads/2014/02/afs study.pdf

Hammer, M. R., Bennett, M. J., \& Wiseman, R. (2003). Measuring intercultural sensitivity: The intercultural development inventory. International Journal of Intercultural Relations, 27(4), 421-443. http://dx.doi.org/10.1016/S0147-1767(03)00032-4

Hansel, B. (1986). The AFS impact study: Final report. AFS Research Reports, July, 1-31. http://www.fondazioneintercultura.it/jb/webfiles/AFS\%20Impact\%20Study.pdf

Holliday, A. (2010). Cultural descriptions as political cultural acts: An exploration. Language and Intercultural Communication, 10(3), 259-272. doi: $10.1080 / 14708470903348572$

Holliday, A. (2011). Intercultural communication and ideology. Thousand Oaks, CA: Sage. http://dx.doi.org/10.1080/14708470903348572

Hunter, B., White, G. P., \& Godbey G. C. (2006). What does it mean to be globally competent?. Journal of Studies in International Education, 10(3), 267-285. http://dx.doi.org/10.1177/1028315306286930

Lähdesmäki, T., \& Wagener, A. (2015). Discourses on governing diversity in Europe: Critical analysis of the paper on intercultural dialogue. International Journal of Intercultural Relations, 44, 13-28.

http://dx.doi.org/10.1016/j.ijintrel.2014.11.002

Landis, D. (2008). Globalization, migration into urban centers, and cross-cultural training. International Journal of Intercultural Relations, 32(4), 337-348.

doi:10.1016/j.ijintrel.2008.04.003 http://dx.doi.org/10.1016/j.ijintrel.2008.04.003

Oetzel, J. G., Soumia, D., \& Kirschbaum, K. (2007). Intercultural conflict from a multilevel perspective: Trends, possibilities, and future directions. Journal of Intercultural Communication Research, 36(3), 183-204. http://dx.doi.org/10.1080/17475750701737124

Perelman, C., \& Olbrechts-Tyteca, L. (1958). Traité de I'argumentation: la nuovelle rhétorique. Paris, FR: Presses Universitaires de France.

Phipps, A. (2014). 'They are bombing now': 'Intercultural Dialogue' in times of conflict. Language and Intercultural Communication, 14(1), 108-124.

http://dx.doi.org/10.1080/14708477.2013.866127

Portera, A. (2008). Intercultural education in Europe: Epistemological and semantic aspect. Intercultural Education, 19(6), 481-491. http://dx.doi.org/10.1080/14675980802568277

Portera, A. (2011). Intercultural and multicultural education. Epistemological and semantic aspects. In C. A. Grant \& A. Portera (Eds.), Intercultural and multicultural education. Enhancing global interconnectedness (pp. 12-30). New York, NY: Routledge. 
Portera, A. (2014). Intercultural competence in education, counselling and psychotherapy. Intercultural Education, 25(2), 157-174. http://dx.doi.org/10.1080/14675986.2014.894176

Putnam, L. (2013). Definitions and approaches to conflict and communication. In J. G. Oetzel \& S. Ting-Toomey (Eds.), The SAGE Handbook of Conflict Communication $\left(2^{\text {nd }}\right.$ ed., pp. 1-39). Thousand Oaks, CA: Sage. http://dx.doi.org/10.4135/9781452281988.n1

Ruffino, R. (Ed.) (1981a). Youth mobility and education. Antwerpen, BE: European Federation for Intercultural Learning.

Ruffino, R. (1981b). Quindici studi sulla mobilità giovanile. Commissione delle Comunità Europee.

Savicki, V. (2008). Experiential and affective education for international educators. In V. Savicki (Ed.), Developing intercultural competence and transformation: Theory, research and application in international education (pp. 74-91). Sterling, VA: Stylus.

Shi-xu (2001). Critical Pedagogy and intercultural communication: Creating discourses of diversity, equality, common goals and rational-moral motivation. Journal of Intercultural Studies, 22(3), 279-293. http://dx.doi.org/10.1080/07256860120094000

Spitzberg, B. H., \& Changnon, G. (2009). Conceptualizing intercultural competence. In D. K. Deardorff (Ed.), The SAGE Handbook of Intercultural Competence (pp. 2-52). Thousand Oaks, CA: Sage.

Ting-Toomey, S. (2007a). Intercultural conflict training: Theory-practice approaches and research challenges. Journal of Intercultural Communication Research, 36(3), 255271. http://dx.doi.org/10.1080/17475750701737199

Ting-Toomey, S. (2007b). Researching intercultural conflict competence. Journal of International Communication, 13(2), 7-30. http://dx.doi.org/10.1080/13216597.2007.9674712

Ting-Toomey, S. (2009). Intercultural conflict competence as a facet of intercultural competence development. In D. K. Deardorff (Ed.), The SAGE Handbook of Intercultural Competence (pp. 100-120). Thousand Oaks, CA: Sage.

Ting-Toomey, S., \& Oetzel, J. G. (2001). Managing intercultural conflict effectively. Thousand Oaks, CA: Sage.

Ting-Toomey, S., \& Oetzel, J. G. (2013a). Introduction to intercultural/international conflict. In J. G. Oetzel \& S. Ting-Toomey (Eds.), The SAGE Handbook of Conflict Communication ( $2^{\text {nd }}$ ed., pp. 635-638). Thousand Oaks, CA: Sage.

http://dx.doi.org/10.4135/9781452281988.n27 http://dx.doi.org/10.4135/9781452281988.n4

Ting-Toomey, S., \& Oetzel, J. G. (2013b). Culture-based situational conflict model. In J. G. Oetzel \& S. Ting-Toomey (Eds.), The SAGE Handbook of Conflict Communication $\left(2^{\text {nd }}\right.$ ed., pp. 763-790). Thousand Oaks, CA: Sage.

http://dx.doi.org/10.4135/9781452281988.n33

Unesco (1987). Youth Exchange. Meeting of Governmental and Non Governmental Officials Responsible for Programmes of Youth Exchange. Rome, IT, 22-26 June.

Unesco (2013). Intercultural competences: Conceptual and operational framework. Paris, FR: Unesco. http://unesdoc.unesco.org/images/0021/002197/219768e.pdf

Wittgenstein, L. (1958). Philosophical investigations. Oxford, UK: Basil Blackwell (2 ${ }^{\text {nd }}$ ed.). Zoletto, D. (2002). Gli equivoci del multiculturalismo. aut aut, 312, 6-18. 
Zoletto, D. (2008). The "value" of cultural diversity: Cultures of integration and global intercultural management. In M. A. Pereyra (Ed.), Changing knowledge and education: Communities, mobilities and new policies in global societies (pp. 349361). Frankurt am Main, D: Peter Lang.

Zoletto, D. (2012). Dall'intercultura ai contesti eterogenei. Presupposti teorici e ambiti di ricerca. Milano, IT: FrancoAngeli. 